Original Research Paper

\title{
Macroeconomic Determinants of Non-Performing Loans: An Empirical Study of Some Arab Countries
}

\author{
${ }^{1}$ Mahmoud Abdelaziz Touny and ${ }^{2}$ Mohamed Abdelhameed Shehab \\ ${ }^{I}$ Department of Economics and Foreign Trade, \\ Faculty of Commerce and Business Administration, Helwan University, Cairo, Egypt \\ ${ }^{2}$ Department of Economics, Faculty of Commerce, Damietta University, Egypt
}

Article history

Received: 6-01-2015

Revised: 3-02-2015

Accepted: 17-04-2015

Corresponding Author: Mahmoud Abdelaziz Touny Department of Economics and Foreign Trade, Faculty of Commerce and Business Administration, Helwan University, Cairo, Egypt Email: mabdelaal@uod.edu.sa

\begin{abstract}
The issue of non-performing loans is one of the factors that reflect the soundness of the banking sector. The main objective of this study is to identify macroeconomic determinants of non-performing loans in some Arab countries through the period 2000-2012 using the dynamic panel data approach. The outcomes of this paper suggest that inflation rate has a negative impact on NPLs, whereas improvement in macroeconomic and financial conditions seems to have a negative impact on the level of NPLs. Regarding the impact of the global financial crisis, the results show that the crisis had a negative impact on the level of NPLs. With regard to household consumption, the outcomes point out to mixed results where this effect seems to be negative in non-petroleum countries but positive in petroleum countries, whereas increasing of government spending is associated with low level of NPLs in both groups of countries. Moreover, an increase of the aggregate debt burden has a positive impact on the level of bad loans whereas expansionary monitory policy and improvement of terms of trade in petroleum countries have a significant negative effect on NPLs but this effect is not clear in non-petroleum countries.
\end{abstract}

Keywords: Non-Performing Loans, Credit Risk, Bad Loan, Loan Default, Macroeconomic Determinants, Debt Burden, Macroeconomic Instability, Dynamic Panel Data Approach

\section{Introduction}

Banks are very important institutions in the financial system of any country and play a fundamental role in the global economy. Therefore, if the financial system does not work properly, this will be reflected negatively on the performance of the whole economy. For this reason, financial stability and soundness of this sector attract the attention of policymakers, regulators and academics.

The issue of Non-Performing Loans (NPLs) is one of the factors that reflect the soundness of the banking sector. Therefore, identifying the determinants of NPLs is very vital to minimize loans' default. The global financial crisis that hit the world in 2008 was also explained by the rapid default of mortgage loans. In the light of these facts, it is therefore understandable why researchers give more interest to investigate and analyse factors responsible for NPLs.

Exploring the determinants of credit default concentrates mainly on two broad factors; macroeconomic and bank specific factors. Macroeconomic factors are central for understanding credit risk and defaults. These factors include economic stability, economic growth, unemployment rate, the cost of servicing debt, the debt burden, stock market index, exchange rate movements, terms of trade and some other factors that are most probably to have a substantial role in explaining the performance of NPLs of the banking system. The bank specific factors which represent endogenous variables include many factors such as rapid credit growth, lenient credit terms, interest margin, credit orientation, regular monitoring of loan quality, poor risk assessment, bank size, banks' operating efficiency and ownership structure of banks (Negera, 2012).

The main objective of this study is to identify the macroeconomic determinants of NPLs in some Arab countries. The banking sector in the Arab countries has witnessed great development in recent years as a result of the great efforts made by most of the Arab states to reform and liberalize it, but it still suffers from a number of challenges dictated by rapid changes in the international and regional economic environment particularly after the Global Financial Crisis and recession in developing countries in 2009. Add to that, 
the revolutions of the Arab Spring contribute to increasing the rate of loan default among clients personal loans and credit cards in some Arab countries such as Egypt, Tunisia, United Emirates and Kuwait. Therefore, exploring the macroeconomic determinants of NPLs can provides some recommendations that could contribute to address this problem and mitigate these risks, which not only could adversely affect the banking sector but also the domestic economy as a whole.

Therefore, the main hypotheses of this research are given in next point:

\begin{abstract}
"Sustained economic growth, low unemployment, improvements of financial conditions and low interest rates seem to be associated with better quality of bank loans and therefore may have a negative effect on the level of NPLs, whereas macroeconomic instability, increasing the cost of debt servicing, deterioration in the terms of trade and worsen financial conditions tend to have a positive effect on the level of NPLs".
\end{abstract}

This paper is organized as follows. Section 2 discusses the theoretical and empirical review, section 3 describes the data and the econometric model, the empirical results are presented and discussed in section 4, whereas section 5 provides conclusion and policy implications of this research.

\section{Literature Review}

Literature review of the determinants of NPLs concentrates on two broad factors; macroeconomic and bank specific factors, in which macroeconomic factors represent exogenous forces in determining NPLs. These macroeconomic determinants have been addressed by many researchers through the past two decades particularly in developed economies. The previous studies in this area have confirmed that macroeconomic conditions are the main source of the systematic risk that reflects in the growth or decline of loan default. This literature investigated the linkage between macroeconomic factors and loan performance by connecting the boom and depression of business cycles with financial vulnerability and stability of the banking sector. In this context, it is assumed that the expansion phase of the economy is accompanied by a relatively low rate of NPLs, as both consumers and firms face a sufficient stream of income and revenues that enable them to service their debts. However, during a recession defaults are more likely as loans in this case are more costly and harder to bear (Ahmad and Bashir, 2013; Louzis et al., 2012).

The primary macroeconomic determinants of NPLs have been extracted from the theoretical literature of lifecycle consumption models. Lawrence (1995) showed that borrowers with low incomes have higher rates of default due to increased risk of facing unemployment and being unable to pay. An increase in the unemployment rate could influence negatively the present and future purchasing power of households and consequently increase the debt burden. In turn, increases in unemployment will be reflected mostly in a decrease of production as a result of the decline in the effective demand. This may result in a decrease in revenues of firms and therefore a decrease in their ability to meet their debt obligations. Accordingly, in periods of high economic growth and low unemployment rates borrowers are more able to support debt, consequently resulting in the decline of NPLs (Bofondi and Ropele, 2011).

Most empirical studies support that deterioration of economic growth and an increase of unemployment rate are significantly associated with high levels of NPLs. Using a data set of Hong Kong for the period 1995-2002, Shu (2002) showed that there is a negative impact of inflation rate and the growth rate of real GDP on the ratio of bad loans to performing loans, however, unemployment rate seems to have insignificant impact on NPLs. Also, Salas and Saurina (2002) confirmed that there is a significant negative contemporaneous effect of GDP growth on the NPL ratio in Spanish commercial and savings banks over the period 1985-1997, whereas unemployment has a positive effect on NPLs. This result is also supported by Delgado and Saurina (2004) as they found that loan loss provisions are negatively related to GDP growth in Spain. Baboucek and Jancar (2005) found that unemployment has a positive impact on the NPL ratio in the Czech banking sector for the period 1993-2006. Add to that, Fofack (2005) revealed a strong causal relationship between NPLs and economic growth where macroeconomic stability and economic growth are associated with a declining level of NPLs. Quagliariello (2007) suggested that there is a negative effect of a decline in GDP growth and an increase of unemployment level on NPLs. Moreover, Das and Ghosh (2007) confirmed that GDP growth has contemporaneous impact on loan default in Indian stateowned banks. In Italy, Bofondi and Ropele (2011) clarified that the annual growth rates of GDP has a negative impact on the quality of household loans, whereas unemployment has a negative effect. Utilizing a data set of 26 advanced countries, Nkusu (2011) clarified that deterioration in the macroeconomic environment as proxied by slower growth, higher unemployment is associated with rising NPLs. Vogiazas and Nikolaidou (2011) verified that investment expenditure and unemployment are among the main factors in explaining the credit risk of the Romanian banking system and they have a negative impact on the declining asset quality. Using dynamic panel data methods, Louzis et al. (2012) found that the an increase of the real GDP growth rate and a decrease of unemployment level contribute significantly in reducing the level of NPLs in the Greek 
banking sector over the period (2003-2009). Further, Castro (2012) indicated that decreasing of GDP growth and increasing of unemployment rate contribute significantly to increasing the rate of NPLs in Greece, Ireland, Portugal, Spain and Italy. Moinescu (2012) also confirmed that GDP growth is the prominent macroeconomic explanatory variable of the fluctuations of NPLs among CEE economies. Another support is provided by Ahmad and Bashir (2013) in Pakistan economy where GDP grow is negatively associated with NPLs. Messai and Jouini (2013) using a sample of 85 banks from Italy, Greece and Spain clarified that NPL ratio varies negatively with the rate of GDP growth and positively with unemployment rate. In a recent study, Mileris (2014) showed that economic deterioration in EU countries with imperfect economic conditions has a negative effect on the debtors' ability to repay their debts. Contrary to the most previous studies, Boudriga et al. (2009) using panel data of 59 countries showed that economic conditions seem to have insignificant impact on loan defaults in developed countries. Also, Bucur and Dragomirescu (2014) did not find a significant relationship between credit risk and real GDP growth rate whereas unemployment seems to be positively related to the credit risk in Romanian banking sector over the period 2008-2013.

On the other hand, macroeconomic instability would have consequences on the loan quality of banks. Both economic theory and empirical evidence strongly support that macroeconomic instability is associated with banking instability and vice versa. High inflation, as an indicator of macroeconomic instability, increases the volatility of business profits because of its unpredictability which in turn increases the probability of firms' loss. Moreover, high inflation may lead to high nominal interest rates especially when loan rates are variable, which is reflected directly in an increase of debt service. An increase in interest rates weakens the capacity of borrowers to service their debts, particularly if loan rates are variable. Therefore, it is expected that a rise in interest rates is positively related to the level of NPLs. On the other side, high inflation may help borrowers whose debt is denominated in nominal terms by reducing the real value of outstanding loans. In turn, stable business environment reduces the risk of the financial deterioration and enables the households to plan their income more safely and manage their personal loans efficiently. Therefore, the relationship between inflation and NPLs can be positive or negative (Bofondi and Ropele, 2011; Negera, 2012).

With regard to the empirical support of the effect of inflation, some studies confirmed the negative relationship between inflation and the level of NPLs (Shu, 2002; Vogiazas and Nikolaidou, 2011; Ahmad and Bashir, 2013; Bucur and Dragomirescu, 2014) but other studies demonstrated that NPLs is positively associated with higher inflation rates (Baboucek and Jancar, 2005; Fofack, 2005) whereas few studies such as Quagliarello (2007) do not find a significant relationship between inflation and loan defaults.

As for the effect of interest rate, there are also mixed evidence from the empirical literature about its effect on the level of NPLs. Some studies verified that interest rate has a positive effect on NPLs (Shu, 2002; Salas and Saurina, 2002; Delgado and Saurina, 2004; Bofondi and Ropele, 2011; Castro, 2012; Moinescu, 2012; Messai and Jouini, 2013). On the other hand, there as some studies indicated that NPLs is negatively associated with the level of interest rate (Fofack, 2005; Ahmad and Bashir, 2013), whereas Das and Ghosh (2007) referred that the real interest rate does not seem to have any significant influence on NPLs.

Other factors which could have a significant impact on the volume of NPLs are financial and real wealth. An increase of asset prices boosts financial and housing wealth which could help borrowers to face unexpected adverse shocks. For example, booming stock markets reflect a positive outlook on firms' profitability and therefore an increase in financial wealth is expected to increase the ability of households to pay their loans and service their debt. Nkusu (2011) confirmed that falling asset prices is associated with high levels of NPLs. Also, Castro (2012) indicated that deterioration of financial conditions contributes significantly to increasing the rate of NPLs. Similarly, increases in real wealth as proxied by house prices may improve the quality of loans. As loans for house purchases are usually mortgage loans, rising house prices reduces the probability of defaulting of households as they can sell their houses and end the loan without defaulting. Therefore, changes in equity or house prices are expected to be negatively associated with the level of NPLs (Shu, 2002).

The aggregate debt burden of households and businesses represents another important variable in explaining the performance of NPLs. Salas and Saurina (2002) clarified that rapid credit expansion contributes positively to the level of NPLs. Add to that, Castro (2012) argued that high debt burdens make debtors more vulnerable to negative shocks and in turn have a negative impact on their wealth or income, which in turn increases the likelihood that they can't cope with their debts' obligations.

International competitiveness of the local economy may also have an effect on the amount of loan default. An appreciation of the exchange rate may have mixed implications. Fofack (2005) showed that the real effective exchange rate has a positive effect on the level of NPLs in some Sub-Saharan African countries with fixed exchange rate regimes. The author argued that the appreciation in the currency makes goods and services produced in that country relatively more expensive and 
thus weakens the competitiveness of export-oriented firms and adversely affects their ability to serve their debt. Another support of this result was by Castro (2012) who confirmed that an appreciation of the real exchange rate results in an increase of the level of NPLs. Also, Moinescu (2012) showed that exchange rate changes exercise positive effects on NPLs ratio. Further, Bucur and Dragomirescu (2014) indicated that credit risk is negatively associated with fluctuations of the foreign exchange rate. On the other hand, appreciation of the real exchange rate can improve the debt-servicing capacity of borrowers who borrow in foreign currency. Add to that, terms of trade could have a significant effect on loan default. Changes in the terms of trade affect credit risk through its effect on borrowers' earnings. Deterioration in terms of trade, especially in countries suffer from lack of diversification, declines the purchasing power in a country. As a result, deterioration of terms of trade is expected to increase the accumulation of NPLs (Bohachova, 2008; Castro, 2012).

Summing up, all these macroeconomic variables have an impact on the volume of NPLs, which may be positive or negative depending on the nature of the economy of each country and the overlapping effects of these variables. The existing empirical studies show that improvements in macroeconomic conditions, such as sustainable economic growth, low levels of unemployment and interest rates are associated with high level of loan quality. Good conditions of macroeconomic climate enhance the ability of debtors to cope with their debt obligations which reduces the level of loan default. However, the results of these studies were not decisive in many cases as some of these variables were significant in some cases and insignificant in other studies. While some of these variables have a positive impact of the level of NPLs in some studies, they have either negative or insignificant effect in other studies. In this study, we try to extend the empirical analysis of this issue at a macro-level to a panel of some Arab countries which have been highly affected by unfavorable economic and financial conditions using a proper dynamic panel data approach.

\section{Data and Methodology}

\section{Data Description}

The dataset consists of a balanced panel of nine Arab countries covering the period from 2000 to 2012. The panel includes five non-petroleum countries (Egypt, Morocco, Tunisia, Jordan and Lebanon) and four Arab Gulf countries (Saudi Arabia, Kuwait, Oman and United Arab Emirates) (We couldn't include more other Arab countries due to the limitation of data available about non-performing loans). All these countries suffered from the problem of loan default during the last decade due to the difficult economic conditions that encounter these countries such as recession and unemployment. According to a report by the Moody's Agency of credit rating in 2013, the ratio of NPLs to total bank loans amounted to $10.2 \%$ in the United Arab Emirates, which is considered a top Gulf country, followed by Bahrain at $7 \%$, Kuwait was estimated at $5.2 \%$, then the Omani banks 2.8\% and Saudi Arabia 2.3\% (Aleqtisadiah Newspaper, 2014). Banks in these countries are still having difficulty recovering bad debts and not quite efficient in evaluating the level of indebtedness of borrowers (Gulfnews, 2015).

With regard to Egypt and Tunisia, NPLs ratio witnessed a high level with a mean value of about 17.5 during the study period (2000-2012) which reached to the highest record at the mid of $2000 \mathrm{~s}$ but showed a declining trend after that. Add to that, the growth in NPLs ratio in Lebanese banks was significant where the mean value of the NPLs ratio during the study period amounted to $9.78 \%$ (Table 1 and Fig. 1). In this fashion, along with the conflict in Syria, a negative impact on Lebanon is also exerted by the weak economic and fiscal situations in Jordan and Egypt.

The data source of NPLs and macroeconomic data is the Global Financial Development Database managed by the World Bank. The credit risk is measured as the ratio between the banks' NPLs to the total gross loans.

The explanatory variables include a broad range of macroeconomic and financial variables which reflect the general state of the economy, economic stability, the cost of servicing debt, the debt burden and financial conditions.

The general state of the economy is proxied by the annual growth rate of real gross domestic product (EG), Capital Investment as a percent of GDP (CI), the value added by the manufacturing sector as a percent of GDP (VMS) and Unemployment Rate (UM). These variables reflect the capacity of households' and firms' to satisfy their debt obligations. High levels of GDP growth reflect higher inflows of income and profits for householders and firms respectively. Capital formation positively supports firms' investment and thus may contribute to reduce firms' loan defaults. Add to that, an increase of the value added by the manufacturing sector reflects higher productivity of manufacturing which in turn boosts up the manufacturing sector's earnings and therefore supports the ability of firms to deal with their debts. Moreover, increases in the level of unemployment reduce the present and future purchasing power of households. Therefore, in periods of favorable economic growth and lower unemployment rate borrowers are able to service their debt, which are assumed to be positively related to the NPLs ratio.

Economic stability is also proxied by two variables which are GDP deflator as an indicator of Inflation Rate (INF) and the annual Growth rate of money supply M2 (GM2). As we stated before, inflation affects the capability of borrowers through different channels and therefore its impact of the performance of NPLs may be positive or negative. 

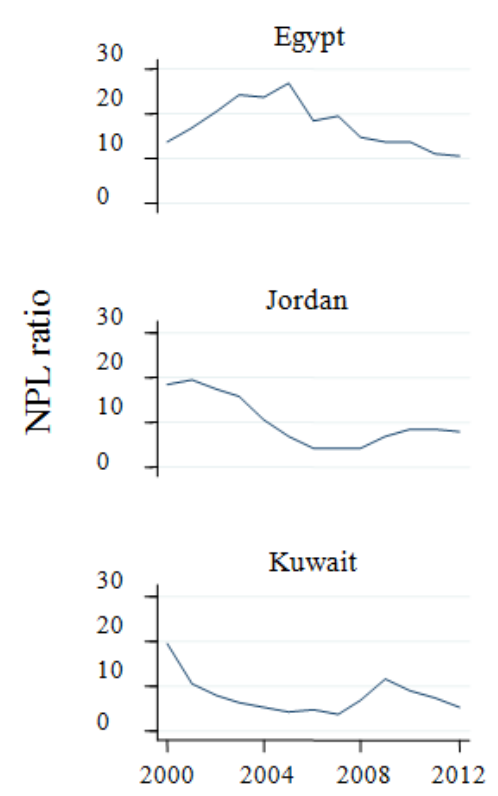
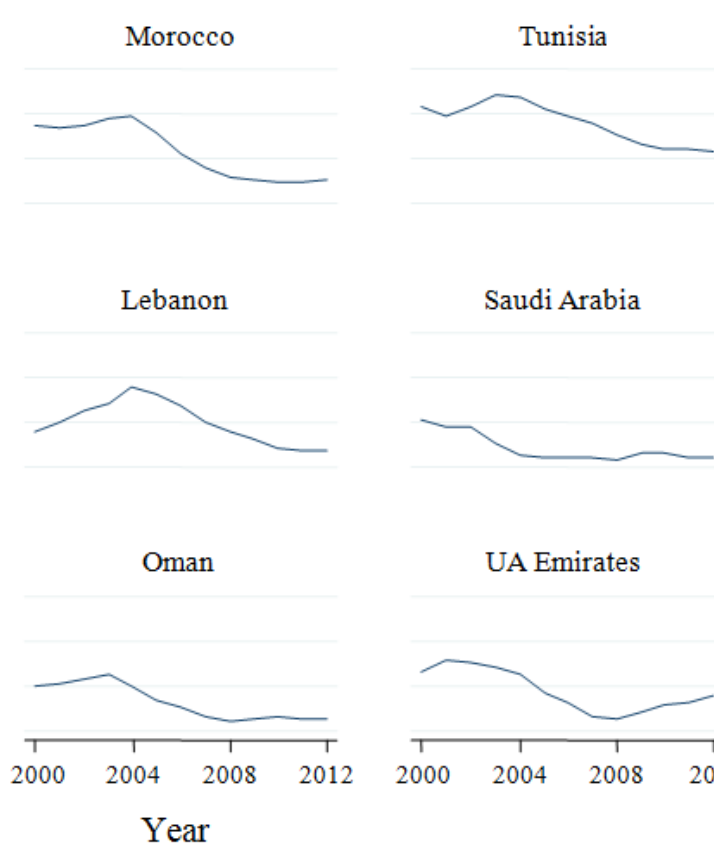

Saudi Arabia
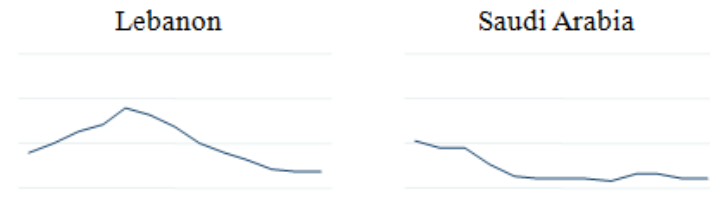

UA Emirates

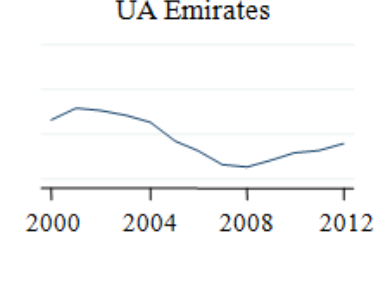

Fig. 1. The performance of non-performing loans as a ratio of total bank loans in some Arab countries through the period (2000-2012)

Table 1. Summary Statistics of non-performing loans ratio in some Arab Countries

\begin{tabular}{lrrl}
\hline Country & Mean & Min. & Max. \\
\hline Egypt & 17.38 & 10.7 & 26.5 \\
Morocco & 11.55 & 4.8 & 19.4 \\
Tunisia & 17.85 & 11.5 & 24.2 \\
Jordan & 10.07 & 4.1 & 19.3 \\
Lebanon & 9.78 & 3.7 & 17.7 \\
Saudi Arabia & 4.18 & 1.4 & 10.4 \\
Kuwait & 7.76 & 3.8 & 19.2 \\
Oman & 6.30 & 2.1 & 12.5 \\
UA Emirates & 8.77 & 2.3 & 15.7 \\
\hline
\end{tabular}

To investigate the cost of debt servicing on the level of bad loans, we include Interest Rates (IR) on bank credit to the private sector within the explanatory variables (For Saudi Arabia and United Arab Emirates, we use the annual interest rate on time deposits as we couldn't reach to a time series of the interest rates on bank credit to the private sector for those countries). It is assumed that high interest rates worsen the quality of loans and therefore NPLs is expected to be positively related with interest rates. Another variable of importance is the ratio of bank credit to private sector to GDP (BCR) as a proxy of the aggregate debt burden of both households and businesses. We expect that a rise in the debt burden results in an increase of NPLs ratio as when credit expands the risk of loan defaults in the future may increase because that expansion might be achieved at the cost of more risky loans (Castro, 2012). However, in economic booms, credit to the private sector as a percent of GDP is expected to be negatively correlated with contemporaneous NPLs (Nkusu, 2011).
Household Consumption (HC) is also considered as an additional indicator of the state of the macroeconomic environment that influences loan defaults. Households' current consumption may reflect the current income of individuals which may results in a decrease in the current level of NPLs. However, the dynamic effect of HC on NPLs may be negative as the increase in debt ceilings due to bank competition enhances households to expand their consumption through borrowing and thus increases their debt obligations in future.

We also consider the effect of the terms of Trade (TR), as measured by the ratio between the price of exports and the price of imports, on the bad loans. Deterioration in the terms of trade means imports become more expensive relative to exports which can weaken the competitiveness of export-oriented firms and adversely affect their ability to service their debt.

Furthermore, financial conditions are proxied by Stock Market Capitalization as percent of GDP (SMC) and Stock Market Return (SMR) which is measured by the growth rate of annual average stock market index. It is expected that high stock market returns and stock market capitalization are associated with a low level of NPLs as improvement in these variables is considered as an indicator of increasing the capacity of individuals and firms to repay their loans. We also use a dummy variable to test the effect of the Global Financial Crisis (GFC) that hit the world in 2008 on the level of NPLs.

\section{Correlation Analysis and Stationarity Test}

Correlation analysis is carried out to check for multicollinearity problem between independent variables. As we have two groups of countries; Golf 
(petroleum) countries and non-petroleum countries that have different features and characteristics which may lead to differences in the determinants of NPLs between these two groups, therefore we estimate our models for each group of these countries.

Tables 2 and 3 show the correlation matrix between the independent variables for the two groups of countries. The correlation matrix indicates that there are some variables that have a relatively high and significant correlation. To avoid the problem of multicollinearity, we estimate more than one model for each group to include variables with low correlation in one model. As a result we estimate two models for non-petroleum countries and three models for petroleum countries.

Another problem needs to be examined and addressed is the problem of stationarity. As we utilize time series models, it is necessary to check if these series are stationary or not. As we use panel data, we apply Levin et al. (2002) panel unit root test. The null hypothesis is that each individual time series contains a unit root against the alternative that each time series is stationary. Table 4 indicates that all variables in both groups of countries are stationary in levels except for EG, HC and GS in non-petroleum countries.

\section{Model Specification}

This study applies the dynamic panel data approach, suggested by Arellano and Bover (1995) and Blundell and Bond (1998). The dynamic approach is adopted in order to account for the time persistence in the NPLs structure. This model uses one-step Generalized Method of Moments (GMM) technique as it is much more consistent and efficient in estimating the coefficients and in controlling for the potential problems of endogeneity, heteroscedasticity and autocorrelation (Arellano and Bover, 1995). In addition, the dynamic GMM estimator can control for unobserved heterogeneity and the persistence of the dependent variable. Add to that, the Arellano-Bond method is designed for small samples with $\mathrm{T} / \mathrm{N} \rightarrow 0$. It is therefore the appropriate estimator since the panel data set has a short time dimension $(\mathrm{T}=13)$ relative to the number of countries $(\mathrm{N}=9)$. One Lag of the dependent variable is included in the set of regressors to capture the effect of omitted explanatory variables and the persistence of NPLs. We don't use the OLS estimator as it is biased and inconsistent in dynamic panel data models even if the error term is not serially correlated. The random effects estimator is also biased in a dynamic panel data model (Baltagi, 2005).

Therefore the basic model can be given by Equation 1:

$$
N P L s_{i t}=\alpha+\delta N P L s_{i t-1}+X_{i t}^{\prime} \beta+\gamma_{i}+\varepsilon_{i t}
$$

$$
\begin{aligned}
& \text { Where: } \\
& N P L s_{i t}=\text { The dependent variable of country (i) at } \\
& \text { time (t) } \\
& X_{i t}^{\prime} \quad=\quad \text { A vector of endogenous and predetermined } \\
& \text { variables } \\
& \mathrm{i}=1, \ldots, \mathrm{N}=\text { Indicates to country } \\
& \mathrm{t}=1, \ldots, \mathrm{T}=\text { The time dimension } \\
& \beta=\text { A vector of coefficients to be estimated } \\
& \gamma_{i}=\mathrm{A} \text { time-invariant unobserved country- } \\
& \text { specific effect } \\
& \varepsilon_{i t} \quad=\text { A vector of disturbances }
\end{aligned}
$$

Therefore, the dependent variable (NPLs) is regressed on its first lag values, on current and first lag values of macroeconomic variables and the deterministic part (constant term). Equation 1 is estimated using one-step Generalized Method of Moments (GMM) suggested by Arellano-Bover/ Blundell Bond Estimation with robust standard errors. We choose the one-step GMM estimator as it is less biased than two-step estimator in small samples.

\section{Empirical Results}

Table 5 and 6 present the empirical results of the dynamic panel models using Arellano-Bover/Blundell Bond Estimation to reveal the macroeconomic determinants of NPLs in both petroleum and nonpetroleum countries. Table 5 includes two models and Table 6 includes 3 models in order to separate between explanatory variables with relatively high correlation. The results of model (1) in Table 5 indicate that Inflation rate (INF) has a negative impact on NPLs ratio. This result supports the viewpoint that inflation can improve borrowers' ability to meet their obligations by eroding the real value of repayment. In addition, most borrowers are business people who can pass over the cost of inflation to consumers and therefore they can retain their ability to repay their loans. This result is confirmed by the results of model (1) in Table 6 for petroleum countries where inflation rate has a significant negative effect on NPLs.

With regard to economic growth, the study suggests a negative impact of economic growth on the performance of NPLs in both petroleum and non-petroleum countries as shown in Table 5, model (1) and Table 6, model (2). This finding is consistent with most previous studies confirming that an improvement in macroeconomic conditions as proxied by the annual growth rate of gross domestic product (EG) increases the ability of both households and firms to repay their borrowed money and therefore reduce the level of NPLs. Another indicator of the general state of the economy is Capital Investment as a percent of GDP (CI). The estimated models in Table 5 and 6 clarify that a high level of capital investment is associated with a low level of NPLs ratio which supports the previous conclusion that NPLs ratio is significantly adjusting to improvement in macroeconomic conditions. 
Table 2. Correlation matrix of explanatory variables for non-petroleum countries

\begin{tabular}{|c|c|c|c|c|c|c|c|c|c|c|c|c|c|c|}
\hline & INF & EG & CI & $\mathrm{HC}$ & GS & VMS & TR & UM & GM2 & SMC & IR & BCR & SMR & GFC \\
\hline$\overline{\mathrm{INF}}$ & 1.00 & & & & & & & & & & & & & \\
\hline $\mathrm{EG}$ & 0.19 & 1.00 & & & & & & & & & & & & \\
\hline CI & -0.14 & $0.27 *$ & 1.00 & & & & & & & & & & & \\
\hline $\mathrm{HC}$ & 0.18 & 0.14 & $-0.26^{*}$ & 1.00 & & & & & & & & & & \\
\hline GS & $-0.36 *$ & 0.09 & $0.29 *$ & -0.03 & 1.00 & & & & & & & & & \\
\hline VMS & 0.21 & -0.08 & -0.20 & $-0.32 *$ & $0.28 *$ & 1.00 & & & & & & & & \\
\hline $\mathrm{TR}$ & $0.41 *$ & -0.01 & -0.02 & -0.18 & $-0.49 *$ & -0.05 & 1.00 & & & & & & & \\
\hline UM & -0.01 & -0.01 & -0.10 & -0.17 & $0.54 *$ & $0.63 *$ & $-0.32 *$ & 1.00 & & & & & & \\
\hline GM2 & $0.35^{*}$ & $0.43^{*}$ & -0.00 & 0.01 & -0.01 & 0.15 & 0.03 & 0.02 & 1.00 & & & & & \\
\hline $\mathrm{SMC}$ & $0.24 *$ & $0.39 *$ & $0.31 *$ & $0.32 *$ & $0.42 *$ & $0.33^{*}$ & -0.05 & $0.25 *$ & $0.35 *$ & 1.00 & & & & \\
\hline IR & 0.23 & -0.01 & $-0.65 *$ & $0.74 *$ & $-0.31 *$ & -0.19 & 0.11 & $-0.32 *$ & 0.11 & -0.01 & 1.00 & & & \\
\hline BCR & $-0.30 *$ & 0.08 & $0.44 *$ & $0.46^{*}$ & $0.46^{*}$ & $-0.34 *$ & $-0.44 *$ & -0.11 & -0.12 & $0.26^{*}$ & 0.06 & 1.00 & & \\
\hline SMR & 0.13 & 0.12 & -0.17 & 0.01 & -0.15 & -0.01 & 0.02 & 0.03 & $0.31 *$ & 0.20 & 0.07 & -0.19 & 1.00 & \\
\hline GFC & $0.37 *$ & -0.11 & $0.39 *$ & -0.00 & -0.21 & -0.09 & $0.39 *$ & -0.18 & -0.14 & -0.02 & -0.20 & 0.10 & $-0.25 *$ & 1.00 \\
\hline
\end{tabular}

Table 3. Correlation matrix of explanatory variables for petroleum countries

\begin{tabular}{|c|c|c|c|c|c|c|c|c|c|c|c|c|c|c|}
\hline & INF & $\mathrm{EG}$ & CI & $\mathrm{HC}$ & GS & VMS & $\mathrm{TR}$ & UM & GM2 & SMC & IR & BCR & SMR & GFC \\
\hline $\mathrm{INF}$ & 1.00 & & & & & & & & & & & & & \\
\hline EG & $0.49^{*}$ & 1.00 & & & & & & & & & & & & \\
\hline CI & -0.15 & -0.10 & 1.00 & & & & & & & & & & & \\
\hline $\mathrm{HC}$ & -0.19 & -0.13 & 0.08 & 1.00 & & & & & & & & & & \\
\hline GS & -0.21 & -0.02 & -0.17 & $-0.65 *$ & 1.00 & & & & & & & & & \\
\hline VMS & -0.19 & 0.13 & $0.54 *$ & $0.33 *$ & -0.06 & 1.00 & & & & & & & & \\
\hline TR & $0.33 *$ & 0.11 & $0.32 *$ & $-0.54 *$ & -0.11 & -0.09 & 1.00 & & & & & & & \\
\hline UM & -0.02 & 0.00 & $0.49 *$ & -0.27 & $0.35^{*}$ & $0.38 *$ & 0.15 & 1.00 & & & & & & \\
\hline GM2 & 0.18 & 0.21 & 0.23 & 0.16 & $-0.37 *$ & 0.24 & 0.18 & 0.01 & 1.00 & & & & & \\
\hline SMC & 0.11 & 0.22 & $-0.28 *$ & $-0.45 *$ & 0.27 & $-0.34^{*}$ & 0.16 & $-0.36 *$ & 0.09 & 1.00 & & & & \\
\hline IR & 0.10 & -0.01 & -0.24 & $-0.36^{*}$ & $0.34 *$ & $-0.50 *$ & -0.10 & 0.22 & -0.03 & 0.15 & 1.00 & & & \\
\hline BCR & -0.14 & $-0.36 *$ & -0.02 & $0.27 *$ & $-0.45^{*}$ & $-0.46^{*}$ & 0.20 & $-0.45 *$ & -0.11 & 0.07 & -0.10 & 1.00 & & \\
\hline SMR & $0.43^{*}$ & $0.43 *$ & -0.09 & -0.00 & 0.05 & 0.13 & -0.18 & -0.06 & 0.19 & $0.38^{*}$ & -0.03 & $-0.31 *$ & 1.00 & \\
\hline GFC & -0.02 & -0.25 & $0.35 *$ & -0.18 & -0.20 & -0.09 & $0.68 *$ & 0.04 & -0.26 & -0.21 & $-0.30 *$ & $0.54 *$ & $-0.40 *$ & 1.00 \\
\hline
\end{tabular}

Table 4. Levin-Lin-Chu Panel Unit Root test; Ho: Panels contain unit roots; Ha: Panels are stationary

\begin{tabular}{|c|c|c|c|c|}
\hline \multirow[b]{2}{*}{ Variable } & \multicolumn{2}{|c|}{ Adjusted t (Non-petroleum Countries) } & \multicolumn{2}{|c|}{ Adjusted t (petroleum Countries) } \\
\hline & Without time trend & With time trend & Without time trend & With time trend \\
\hline$\overline{N P L}$ & $-2.66^{* * *}$ & $-8.21^{* * *}$ & $-2.99^{* * *}$ & -0.95 \\
\hline $\mathrm{INF}$ & $-2.80^{* * *}$ & $-3.16^{* * *}$ & $-3.94^{* * *}$ & $-2.77^{* * *}$ \\
\hline EG & -0.137 & 0.96 & $-3.27^{* * *}$ & $-3.25^{* * *}$ \\
\hline $\mathrm{CI}$ & $-1.54^{*}$ & $-3.14^{* * *}$ & $-2.72^{* * *}$ & $-2.01^{* *}$ \\
\hline $\mathrm{HC}$ & 3.22 & 0.76 & $-1.44^{*}$ & $-2.46^{* * *}$ \\
\hline GS & -0.18 & -0.08 & $-2.25^{* *}$ & $-1.93^{* *}$ \\
\hline VMS & $-2.30^{* * *}$ & $-1.49^{*}$ & $-3.28^{* * *}$ & 1.71 \\
\hline TR & $-2.13^{* *}$ & $-2.92^{* * *}$ & -0.81 & $-1.58^{* *}$ \\
\hline UM & $-2.97^{* * *}$ & $-1.60^{*}$ & $-1.87^{* *}$ & $-1.29^{*}$ \\
\hline GM2 & $-2.65^{* * *}$ & $-2.43^{* * *}$ & $-1.39^{*}$ & $-1.54^{*}$ \\
\hline SMC & $-1.66^{* *}$ & $-1.42^{*}$ & $-1.51^{*}$ & $-2.44^{* * *}$ \\
\hline IR & $-3.01^{* * *}$ & $-3.65^{* * *}$ & $-3.50^{* * *}$ & $-4.57^{* * *}$ \\
\hline BCR & 0.17 & $-2.22^{* *}$ & $-2.08^{* *}$ & $-3.23^{* * *}$ \\
\hline SMR & $-1.77^{* *}$ & $-1.71^{* *}$ & $-1.41^{*}$ & $-2.64^{* * *}$ \\
\hline
\end{tabular}

Note:* indicates rejection of null hypothesis of non-stationary at $10 \%$

$* *$ indicates rejection of null hypothesis of non-stationary at $5 \%$

$* * *$ indicates rejection of null hypothesis of non-stationary at $1 \%$

Unemployment Rate (UM) on the other hand has a significant positive impact on the level of NPLs in both petroleum and non-petroleum countries as shown in model (1) and (2) in Table 5 and model (2) in Table 6. This result confirms that an increase of unemployment level negatively influences the ability of households to meet their repayment schedules.
Another macroeconomic indicator that negatively affects the level of NPLs is Government Spending (GS). An increase of government spending is associated with a low level of NPLs ratio as shown in Table 5 and 6 . An explanation of this relationship is an increase of government spending reflects an increase of compensation of employees and increased spending on 
social benefits which in turn contributes to alleviate the debt burden of these employees.

The results also indicate that the current level of the value added by the manufacturing sector as a percent of GDP (VMS) has a negative but insignificant effect on the level of NPLs in both petroleum and non-petroleum countries, whereas this seems to be positive and significant with the first lag of VMS in non-petroleum countries as reported by model (1) in Table 5 and model (2) in Table 6 . Increasing the value added of the industrial sector is expected to attract more industrial investments and with the increased liquidity of commercial banks and competition between banks to attract more loans' clients drive banks to follow an expansionary and lenient lending policy, which results in granting loans to institutions with low financial solvency and therefore leads to increase the debt obligations of the industrial sector and consequently increases the volume of NPLs.

An increase of Household Consumption (HC) may reflect an increase of current income and an improvement of economic conditions which in turn increase the capability of borrowers to meet the obligations of their loans. As De Long and Summers (1991) argue, increases in consumption and investment stimulate aggregate expenditure, which subsequently enhance economic growth and thus lead to an improvement in loan quality. This conclusion is supported by the sign of the current level of HC in model (1) of Table 5 for non-petroleum countries where it is negative and significant. However, the sign of the current level of $\mathrm{HC}$ in petroleum countries as reported in model (3) of Table 6 is positive and significant at $1 \%$ level of significance. This positive impact is related to the expansion of household consumption in petroleum countries through loans due to the low level of the interest rate in these countries on consumption loans. As the interest rate increases in the economy, the low quality borrowers have a difficulty to pay back their loans and therefore increase the level of loan default. This result is supported by the positive and significant effect of the variable of Interest Rate (IR) in both petroleum and non-petroleum countries.

Regarding the effect of the aggregate debt burden of both households and businesses as proxied by (BCR), the outcomes of the estimated models in both petroleum and non-petroleum countries (model (2) in Table 5 and model (1) in Table 6) refer to a positive and significant association between BCR and the level of NPLs in the subsequent period. This result is consistent with Castro (2012) who argued that when credit expands or grows faster, the risks of NPLs will increase in the future because the expansion in lending may be at the expense of more high-risk loans and this effect may not be at the same time, but it may take some time. This result implies that banks which take greater risks tend to have a high level of NPLs. Add to that, increasing the burden of private debt makes debtors more likely to negative shocks that affect their income and therefore decreases their ability to payback their loans.

Both the level and lag structure of the growth rate of M2 (GM2) as an indicator of monetary policy record a negative and significant impact on the level of NPLs in petroleum countries (model (1), Table 6). This result is consistent with Ahmad and Ariff (2007) and Vogiazas and Nikolaidou (2011) who argued that expansionary monitory policy will decrease the interest rate, which in turn reduces the cost of borrowing. Also, an increase in money supply will stimulate investment and consumption and consequently will increase the income and therefore increase the ability of debtors to meet their loan obligations. However, the effect of GM2 in nonpetroleum countries seems to be positive but insignificant even at 5 percentage point of significance. According to IS/LM model, the effect of expansionary monetary policy on income and therefore the ability of borrows to payback their loans depends on the elasticity of IS curve to changes in interest rate. When IS curve is inelastic, an increase of M2 will result in a decrease in interest rate but will not be reflected largely on income.

With respect to Terms of Trade (TOT), the results suggest a negative association with NPLs as reported by the sign of the level of TOT in petroleum countries which is significant at $5 \%$ (model (2), Table 6). Deterioration of TOT means imports become more expensive relative to exports and thus export earnings are insufficient to meet the demand of imports. Therefore, falling TOT affects negatively on the ability of borrowers especially for exported oriented firms and consequently increases banks' credit risk. However, the sign of the coefficient of this variable appears to be positive in level and negative for the first lag in nonpetroleum countries (model (2), Table 5). This can be explained by the pattern of TOT in both petroleum and non-petroleum countries as shown in Fig. 2 where TOT witnessed an increasing trend during the period study in petroleum countries which affects negatively on the level of NPLs. However, this trend display dispersed or minor fluctuations in non-petroleum countries which might mean that simple nominal changes in TOT are not as relevant to erode borrowers' profitability or purchasing power due to changes in the real exchange rate.

As expected, an improvement in financial conditions as proxied by Stock Market Capitalization as percent of GDP (SMC) and Stock Market Return (SMR) records a negative impact on the level of NPLs in both petroleum and non-petroleum countries. An increase of the asset prices and stock market capitalization is expected to decrease households' and firms' probability of defaulting on loans since it gives them additional resources for servicing their debts. These results confirm that a good stock market performance contributes to reduce the credit risk. 
Mahmoud Abdelaziz Touny and Mohamed Abdelhameed Shehab / American Journal of Economics and Business Administration 2015, 7 (1): 11.22 DOI: 10.3844/ajebasp.2015.11.22

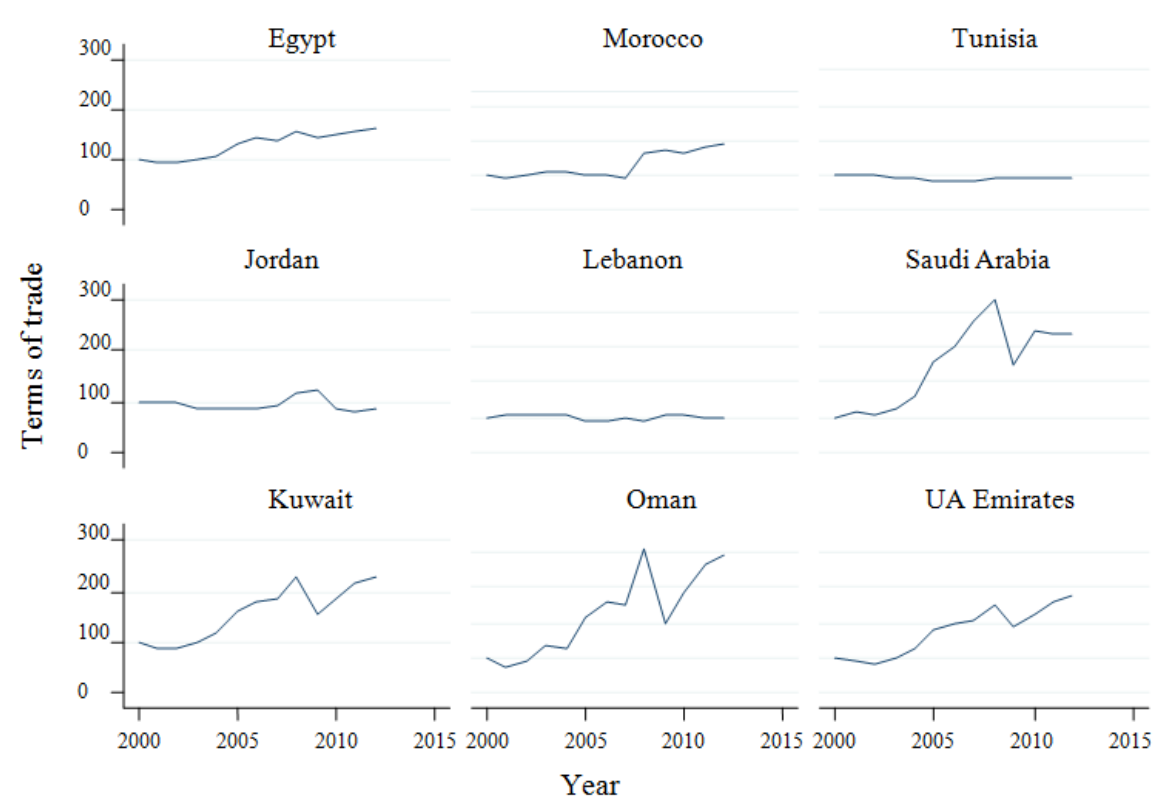

Fig. 2. The pattern of Terms of Trade (TOT) in sample countries through the period (2000-2013)

Table 5. Determinants of non-performing loans in non-petroleum countries using Arellano-Bover/ Blundell bond estimation

\begin{tabular}{|c|c|c|c|c|}
\hline \multirow{2}{*}{$\begin{array}{l}\text { Explanatory } \\
\text { variables }\end{array}$} & \multicolumn{2}{|l|}{ Model (1) } & \multicolumn{2}{|l|}{ Model (2) } \\
\hline & $\beta$ & $\mathrm{Z}$ & $\beta$ & $\mathrm{Z}$ \\
\hline L.NPL & $0.698^{* * *}$ & 13.96 & $0.763^{* * *}$ & 12.96 \\
\hline INF & $-0.189^{* * *}$ & -4.03 & -- & -- \\
\hline L.INF & $-0.051^{*}$ & -1.77 & -- & -- \\
\hline CI & $-0.249^{* * *}$ & -14.69 & - & -- \\
\hline L.CI & 0.056 & 0.75 & -- & -- \\
\hline $\mathrm{HC}$ & $-0.216^{* * *}$ & -4.44 & -- & -- \\
\hline L.HC & $0.121^{*}$ & 1.77 & -- & -- \\
\hline VMS & -0.458 & -1.61 & -- & -- \\
\hline L.VMS & $0.607^{* *}$ & 2.20 & --- & -- \\
\hline GS & $-0.119^{*}$ & $\begin{array}{l}2.20 \\
-1.70\end{array}$ & -- & -- \\
\hline UM & $0.199^{*}$ & 1.94 & $0.281^{* *}$ & 1.98 \\
\hline IR & $0.291^{* * *}$ & 3.27 & $0.121^{* *}$ & 2.11 \\
\hline EG & -- & -- & $-0.229^{* *}$ & -2.13 \\
\hline L.EG & -- & -- & -0.058 & -0.54 \\
\hline $\mathrm{TR}$ & -- & -- & $0.038^{* *}$ & 2.04 \\
\hline L.TR & -- & -- & $-0.031^{*}$ & -1.82 \\
\hline GM2 & -- & -- & 0.004 & 0.05 \\
\hline L.GM2 & -- & -- & $0.089^{*}$ & 1.82 \\
\hline SMC & -- & -- & $-0.017^{* * *}$ & -3.13 \\
\hline L.SMC & -- & -- & 0.0002 & 0.04 \\
\hline BCR & -- & -- & $-0.092^{*}$ & -1.84 \\
\hline L.BCR & -- & -- & $0.113^{* * *}$ & 2.86 \\
\hline SMR & -- & -- & 0.010 & 1.53 \\
\hline L.SMR & -- & -- & $-0.028^{* * *}$ & -5.34 \\
\hline GFC & -- & -- & $-2.361^{* * *}$ & -6.51 \\
\hline Const. & $11.201^{* * *}$ & 3.12 & -1.063 & -0.73 \\
\hline No. of Obs. & 60 & 60 & & \\
\hline Wald chi2 $(4)$ & $33.63^{* * *}$ & $510.20^{* * *}$ & & \\
\hline $\mathrm{AB}$ test for autocorrelation (2) & 0.567 & 0.801 & & \\
\hline
\end{tabular}


Table 6. Determinants of non-performing loans in petroleum countries using Arellano-Bover/ Blundell Bond Estimation

\begin{tabular}{|c|c|c|c|c|c|c|}
\hline \multirow[b]{2}{*}{ Explanatory variables } & \multicolumn{2}{|l|}{ Model (1) } & \multicolumn{2}{|l|}{ Model (2) } & \multicolumn{2}{|l|}{ Model (3) } \\
\hline & $\beta$ & Z & $\beta$ & Z & $\beta$ & $\mathrm{Z}$ \\
\hline L.NPL & $0.542^{* * *}$ & 4.51 & $0.665^{* * *}$ & 4.50 & $0.765^{* * *}$ & 7.42 \\
\hline INF & $-0.128^{* * *}$ & -6.46 & -- & -- & -- & -- \\
\hline L.INF & $-0.060^{* *}$ & -2.33 & -- & -- & -- & -- \\
\hline GS & $-0.463^{* * *}$ & -3.11 & -- & -- & -- & -- \\
\hline L.GS & 0.144 & 0.83 & -- & -- & -- & -- \\
\hline GM2 & $-0.870^{* * *}$ & -2.71 & -- & -- & $-0.045^{*}$ & -1.86 \\
\hline L.GM2 & $-0.057^{* *}$ & -2.00 & -- & -- & $-0.052^{* * *}$ & -4.03 \\
\hline IR & -0.240 & -1.20 & -- & -- & -- & -- \\
\hline L.IR & $0.455^{* *}$ & 2.16 & -- & -- & -- & -- \\
\hline BCR & -0.013 & -0.35 & -- & -- & -- & -- \\
\hline L.BCR & $0.069^{* * *}$ & 6.99 & -- & -- & -- & -- \\
\hline $\mathrm{CI}$ & $-0.102^{* *}$ & -2.34 & -- & -- & -- & -- \\
\hline EG & -- & -- & $-0.132^{* * *}$ & -3.78 & -- & -- \\
\hline L.EG & -- & -- & 0.011 & 0.26 & -- & -- \\
\hline TR & -- & -- & $-0.016^{* *}$ & -1.97 & -- & -- \\
\hline L.TR & -- & -- & 0.005 & 0.47 & -- & -- \\
\hline SMC & -- & -- & $-0.016^{* *}$ & -2.40 & -- & -- \\
\hline L.SMC & -- & -- & 0.010 & 1.12 & -- & -- \\
\hline VMS & -- & -- & -0.051 & -0.19 & -- & -- \\
\hline $\mathrm{HC}$ & -- & -- & -- & -- & $0.050^{* * *}$ & 5.20 \\
\hline UM & -- & -- & -- & -- & $0.095^{* * *}$ & 4.31 \\
\hline SMR & -- & -- & -- & -- & $-0.020^{* * *}$ & -4.54 \\
\hline L.SMR & -- & -- & -- & -- & 0.005 & 0.56 \\
\hline GFC & -- & -- & -- & -- & 1.345 & 1.37 \\
\hline L.GFC & -- & -- & -- & -- & $-1.505^{* *}$ & -2.17 \\
\hline Const. & $15.972^{* * *}$ & 3.21 & 4.986 & 1.16 & -- & -- \\
\hline No. of Obs. & 48 & 48 & 48 & & & \\
\hline Wald chi2 (3) & $146.76^{* * *}$ & $54.40^{* * *}$ & $85.04^{* * *}$ & & & \\
\hline \multicolumn{2}{|c|}{ AB test for autocorrelation (2) } & -0.781 & 1.136 & -1.192 & & \\
\hline
\end{tabular}

Note:* indicates rejection of null hypothesis of non-stationary at $10 \%$

$* *$ indicates rejection of null hypothesis of non-stationary at $5 \%$

$* * *$ indicates rejection of null hypothesis of non-stationary at $1 \%$

At last, the Global Financial Crisis (GFC) started in 2008 seems to have a negative effect on the level of loan defaults in Arab countries. Because of the negative effects that accompanied the beginning of the global financial crisis in 2008 and early 2009 in the developed countries, the banking system in many Arab countries has been initiated to take more stringent measures on the lending process, fearing of a repeat of what happened in the developed countries. These procedures resulted in a decline in the volume of lending, especially those loans with high-risk, which negatively reflected on the volume of NPLs during this period. Therefore, the Arab banks are generally not affected by the global financial crisis, except in narrow limits and in limited cases, which may be due to the strength of their financial positions and the strict control by central banks and the application of Basel and few cases of corruption in the granting of credit. In this regard, the Central Bank of Egypt for instance has established rules for the practice of the banks to the activities of the mortgage not exceed $5 \%$ of the total loan portfolio of the bank. As well as, these rules include the proportionality between maturities of bank's resources and bank term maturities of mortgage loans. In addition, the Central Bank prohibited any bank to put more than $10 \%$ of the total deposits at another external bank to avoid the risk of bankruptcy. Moreover, the volume of banks' activities has also declined in the area of retail banking (personal loans-car finance loans-real estate finance, etc.) as a result of the expected decline in the aggregate demand for consumption goods (Lotfi, 2009).

Because causality may run in both directions from the dependent variable and independent variables, these regressors may be correlated with the error term. Add to that, time-invariant country characteristics, such as geography and demographics, may be correlated with the explanatory variables. Moreover, the presence of the lagged dependent variable gives rise to autocorrelation. In order to test for serial correlation in the error term of the estimated models, we conduct the Arellano-Bond test for autocorrelation in the first-differenced errors where the null hypothesis is there is no autocorrelation. Because the first difference of independently and identically distributed idiosyncratic errors will be serially correlated, rejecting the null hypothesis of no serial 
correlation in the first-differenced errors at order one does not imply that the model is misspecified, but rejecting the null hypothesis at higher orders implies that the moment conditions are not valid. As shown in all estimated models, the value of the Arellano-Bond test is insignificant at order (2) and therefore we can't reject the null hypothesis of no autocorrelation.

\section{Conclusion and Policy Implications}

The issue of NPLs is one of the factors that reflect the soundness of the banking sector. Therefore, identifying the determinants of NPLs is very vital to minimize loans' default. The main objective of this study is to identify macroeconomic determinants of NPLs in some Arab countries through the period 2000-2012 using the dynamic panel data approach suggested by Arellano and Bover (1995) and Blundell and Bond (1998). The outcomes of this paper suggest that inflation rate has a negative impact on NPLs. As expected, improvement in macroeconomic conditions as proxied by economic growth, capital investment as a percent of GDP and a low level of unemployment seems to have a negative impact on the level of NPLs as it increases the ability of both households and firms to repay their loans. With regard to household consumption, the outcomes point out to mixed results where this effect seems to be negative in non-petroleum countries but positive in petroleum countries, whereas increasing of government spending is associated with a low level of NPLs in both groups of countries. Moreover, an increase of the aggregate debt burden has a positive impact on the level of bad loans which implies that banks with high-risk loans tend to have a high level of NPLs. The results also confirm that expansionary monitory policy and improvement of terms of trade in petroleum countries has a significant negative effect on NPLs, however this effect is not clear in non-petroleum countries. While improvement in financial conditions suggest a negative impact on the level of NPLs in both petroleum and nonpetroleum countries, the global financial crisis started in 2008 seems to have a negative effect on the level of loan defaults in both groups of countries which may reflect the stringent measures on the lending process undertaken by the banking system in many Arab countries during this period.

In terms of policy implications, this paper can provide some implications and recommendations in this regards. First, the management of commercial banks should give more attention to macroeconomic factors when they manage the credit risk of their loans. Understanding the interactions between macroeconomic indicators and NPLs can help banks to manage their credit risk more effectively. So, banks can use the performance of macroeconomic conditions such as economic growth, interest rate, inflation rate, unemployment rate, household consumption and financial conditions to predict the performance of their bad loans in order to avoid the possibility of increasing the level of loan defaults. For example, the commercial banks should take more precautionary measures against the expansion of credit during periods of economic recession. Banks also should allocate credit more efficiently by lending only good credit history borrowers to reduce the burden of their loans and therefore reduce the level of NPLs.

Other recommendations can be given to the governments to reduce the level of NPLs through providing incentives to investors to promote economic growth and reducing the level of unemployment by improving infrastructure and exploring new international markets through doing agreements for free trade especially within Arab countries in order to promote external competitiveness and improve terms of trade.

For researchers, as this paper concentrates mainly on macroeconomic determinants, this work can be extended by exploring other determinants of NPLs to cover micro and sectoral factors.

\section{Acknowledgement}

The corresponding author would like to provide his thanks to faculty of Commerce and Business Administration, Helwan University.

\section{Funding Information}

The authors are the only source of funding for this paper.

\section{Author's Contributions}

Mahmoud Abdelaziz Touny and Mohamed Abdelhameed Shehab: Designed the framework and objectives of the research. Designed research methodology. Formulated the study model. Participated in preparing and writing the theoretical part and previous studies (literature review). Estimated the models, analyzed and interpreted the results. Participated in revising the paper.

\section{Ethics}

This article is original and contains unpublished material. The corresponding author confirms that all of the other authors have read and approved the manuscript and no ethical issues involved.

\section{References}

Ahmad, F. and T. Bashir, 2013. Explanatory power of macroeconomic variables as determinants of nonperforming loans: Evidence from Pakistan. World Applied Sci. J., 22: 243-255. 
Ahmad, N.H. and M. Ariff, 2007. Multi-country study of bank credit risk determinants. Int. J. Banking Finance, 5: 135-152.

Aleqtisadiah Newspaper, 2014. Issue 7518, 12/5/2014.

Arellano, M. and O. Bover, 1995. Another look at the instrumental variable estimation of errorcomponents models. J. Econometrics, 68: 29-51. DOI: 10.1016/0304-4076(94)01642-D

Baboucek, I. and M. Jancar, 2005. Effects of macroeconomic shock to the quality of the aggregate loan portfolio. Working Paper 1, Czech National Bank.

Baltagi, B.H., 2005. Econometric Analysis of Panel Data. 3rd Edn., John Wiley and Sons Ltd., Chichester, UK.

Blundell, R. and S. Bond, 1998. Initial conditions and moment restrictions in dynamic panel data models. J. Econometrics, 87: 115-143. DOI: $10.1016 / \mathrm{S} 0304-4076(98) 00009-8$

Bofondi, M. and T. Ropele, 2011. Macroeconomic determinants of bad loans: Evidence from Italian banks. Bank of Italy Occasional Paper No. 89.

Bohachova, O., 2008. The impact of macroeconomic factors on risks in the banking sector: A crosscountry empirical assessment. IAW Discussion Paper 44.

Boudriga, A., N.B. Taktak and S. Jellouli, 2009. Banking supervision and nonperforming loans: A cross-country analysis. J. Financ. Econ. Policy, 1: 286-318. DOI: 10.1108/17576380911050043

Bucur, I.A. and S.E. Dragomirescu, 2014. The influence of macroeconomic conditions on credit risk: Case of Romanian banking system. Studies Scientific Res. Econ. Edition, 19: 84-95.

Castro, V., 2012. Macroeconomic determinants of the credit risk in the banking system: The case of the GIPSI. Universidade de Coimbra, NIPE.

Das, A. and S. Ghosh, 2007. Determinants of credit risk in Indian state-owned banks: An empirical investigation. Econ. Issu., 12: 48-66.

De Long, J.B. and L.H. Summers, 1991, Equipment investment and economic growth. Q. J. Econ., 106: 445-502. DOI: $10.2307 / 2937944$

Delgado, J. and J. Saurina, 2004. Credit risk and loan loss provisions: An Analysis with macroeconomic variables. Banco de Espana.

Fofack, H.L., 2005. Nonperforming loans in SubSaharan Africa: Causal analysis and macroeconomic implications. Policy Research Working Paper, Southern Africa.

Gulfnews, 2015. Gulf news banking.

Lawrence, E.C., 1995. Default and the life cycle model. J. Money Credit Banking, 27: 939-954.

DOI: $10.2307 / 2077781$
Levin, A., C.F. Lin and C.S.J. Chu, 2002. Unit root tests in panel data: Asymptotic and finite-sample properties. J. Econ., 108: 1-24. DOI: $10.1016 / \mathrm{S} 0304-4076(01) 00098-7$

Lotfi, A., 2009. The global financial crisis: Reasons the consequences-the confrontation. Proceedings of the Conference "The implications of the global financial crisis and its impact on the economies of Arab countries", Arab Administrative Development Organization, Apr. 4-5, Sharm El Sheikh, Egypt.

Louzis, D., A. Vouldis and V. Metaxas, 2012. Macroeconomic and bank-specific determinants of non-performing loans in Greece: A comparative study of mortgage, business and consumer loan portfolios. J. Banking Finance, 36: 1012-1027. DOI: $10.1016 /$ j.jbankfin.2011.10.012

Messai, A. and F. Jouini, 2013. Micro and macro determinants of non-performing loans. Int. J. Econ. Financ. Issu., 3: 852-860.

Mileris, R., 2014. Macroeconomic factors of nonperforming loans in commercial banks. Ekonomika, 93: 22-39.

Moinescu, B.G., 2012. Determinants of nonperforming loans in Central and Eastern European Countries: Macroeconomic indicators and credit discipline. Rev. Econ. Bus. Studies, 5: 47-58.

Negera, G.W., 2012. Determinants of non-performing loans: The case of Ethiopian banks. University of South Africa.

Nkusu, M., 2011. Nonperforming loans and macrofinancial vulnerabilities in advanced economies. IMF Working Paper, WP/11/161.

Quagliariello, M., 2007. Banks' riskiness over the business cycle: A panel analysis on Italian intermediaries. Applied Financ. Econ., 17: 119-138. DOI: 10.1080/09603100500486501

Salas, V., J. Saurina, 2002, Credit risk in two institutional regimes: Spanish commercial and savings banks. J. Financ. Services Res., 22: 203-224. DOI: $10.1023 / \mathrm{A}: 1019781109676$

Shu, C., 2002. The impact of macroeconomic environment on the asset quality of Hong Kong's banking sector. Hong Kong Monetary Authority Research Memorandums.

Vogiazas, S.D. and E. Nikolaidou, 2011. Investigating the determinants of nonperforming loans in the Romanian banking system: An empirical study with reference to the Greek crisis. Econ. Res. Int., 2011: 1-13. DOI: $10.1155 / 2011 / 214689$ 